\title{
A study of the interaction between Helicobacter pylori and components of the human fibrinolytic system
}

A. Yarzábal ${ }^{1}$, L. Avilán ${ }^{1}$, K. Hoelzl2 ${ }^{2}$ M. de Muñoz², J. Puig ${ }^{1}$ and I. Kansau ${ }^{2}$

\author{
${ }^{1}$ Laboratorio de Biología y Medicina Experimental, Facultad de Ciencias, and \\ 'Laboratorio de Microbiología, Facultad de Medicina, Universidad de Los Andes, \\ Mérida, Venezuela
}

\section{Correspondence \\ L. Avilan \\ LABIO MEX, Facultad de Ciencias \\ Universidad de Los Andes \\ Apartado Postal 281 \\ Mérida 5101 \\ Venezuela \\ Fax: + 58-74-63-4587 \\ E-mail: avilan@ ciens.ula.ve}

Research supported by CONICIT (No. S1-97001300) and CDCHT-ULA (No. C-925-98-03-B).

Received December 1, 1999 Accepted June 12, 2000

\section{Abstract}

The interaction of plasminogen, tissue plasminogen activator (t-PA) and urokinase with a clinical strain of Helicobacter pylori was studied. Plasminogen bound to the surface of $H$. pylori cells in a concentration-dependent manner and could be activated to the enzymatic form, plasmin, by t-PA. Affinity chromatography assays revealed a plasminogen-binding protein of $58.9 \mathrm{kDa}$ in water extracts of surface proteins. Surface-associated plasmin activity, detected with the chromogenic substrate CBS 00.65, was observed only when plasminogen and an exogenous activator were added to the cell suspension. The two physiologic plasminogen activators, t-PA and urokinase, were also shown to bind to and remain active on the surface of bacterial cells. $\varepsilon$ Aminocaproic acid caused partial inhibition of t-PA binding, suggesting that the kringle 2 structure of this activator is involved in the interaction with surface receptors. The activation of plasminogen by tPA, but not urokinase, strongly depended on the presence of cells and a 25-fold enhancer effect on the initial velocity of activation by t-PA compared to urokinase was established. Furthermore, a relationship between cell concentration and the initial velocity of activation was demonstrated. These findings support the concept that plasminogen activation by t-PA on the bacterial surface is a surface-dependent reaction which offers catalytic advantages.

\section{Introduction}

Plasminogen, a 92-kDa glycoprotein present in plasma and extracellular fluids, is the main component of the fibrinolytic system (1). It circulates in plasma as an inactive zymogen which, under different conditions, could be activated to the active form, plasmin, by plasminogen activators (PA) such as the tissue-type PA (t-PA) and urokinase. The activation reaction involves the hydrolysis of

\section{Key words}

- Helicobacter pylori

- Plasminogen

- t-PA

- Urokinase

- Plasminogen activation 
merous cell types and fibrin clots facilitates plasmin generation, resulting in an enhancement of the catalytic efficiency $(7,8)$; furthermore, surface plasmin cannot be regulated efficiently by host inhibitors such as $\alpha_{2}$-antiplasmin (9).

It has been recently established that binding and activation of human plasminogen on the surface of bacterial cells may be a common mechanism used by invasive bacteria to facilitate movement through normal tissue barriers $(10,11)$. Several species generate their own plasminogen activators: this is the case of group A streptococci and Staphylococcus aureus, which secrete streptokinase and staphylokinase, respectively, two bacterial PAs widely used in the therapy of acute myocardial infarction (12). Other pathogens, not known to produce a PA, may be capable of using host PAs to generate surface plasmin activity, a mechanism which is predicted to be less efficient (11). These organisms can possibly express surface receptors for eukaryotic activators which enable them to acquire plasmin-like enzymatic activity in the human host (10).

Helicobacter pylori is a gram-negative human pathogen that colonizes the gastric mucosa and is associated with various stomach and duodenal disorders such as active chronic gastritis, peptic ulceration and possibly gastric carcinoma (13). Like other bacterial pathogens, $H$. pylori expresses surface proteins with affinity for several human proteins, components of the mammalian extracellular matrix such as laminin, vitronectin, collagen types I and IV and plasminogen (14-18). Plasminogen binding to the surface of $H$. pylori has been shown to be inhibited by lysine, lysine analogues and miniplasminogen (fifth kringle and catalytic domain (1)), suggesting an important role of the fifth kringle structure of the zymogen which possibly interacts with two surface proteins of 42 and $57 \mathrm{kDa}$ (19).

In the present study we have examined the binding of plasminogen and its activa- tion by t-PA and urokinase on the surface of an $H$. pylori clinical isolate. The effect of bacterial cells on plasminogen activation was studied. In addition, the capability of $H$. pylori to bind other components of the plasminogen system such as t-PA and urokinase was also explored.

\section{Material and Methods}

\section{Bacterial isolates}

A clinical H. pylori isolate was obtained from a patient with gastric ulcer at the Hospital Universitario de Los Andes (HULA), University of Los Andes, Mérida, Venezuela. Bacteria were recovered from gastric biopsies collected by endoscopy. The isolate represents a single colony obtained from a biopsy, which was processed for Gram staining, urease test and histology as well as $H$. pylori culture, as previously described (20). In some experiments, comparisons were made among different clinical isolates obtained as previously described.

In order to prepare cell suspensions, $H$. pylori cells incubated for 6-7 days under microaerophilic conditions on blood-agar plates were collected in sterile PBS $(0.14 \mathrm{M}$ $\mathrm{NaCl}, 0.06 \mathrm{M}$ sodium phosphate, $\mathrm{pH}$ 7.2), washed twice and resuspended in the same buffer.

\section{Reagents}

The synthetic substrate for plasmin, methylmalonyl-4-hydroxyprolyl-arginylparanitroanilide (MM-Hyp-Arg-pNA or CBS 00.65) was purchased from Diagnostica STAGO (Asnières, France). All other reagents, unless specified, were obtained from Sigma Chemical Co. (St. Louis, MO, USA). Human plasminogen was purified on lysineSepharose 4B (Pharmacia, Uppsala, Sweden) from blood of human donors, according to the method of Deutsch and Mertz (21). Briefly, proteins bound to the column were 
eluted with $50 \mathrm{mM} \varepsilon$-aminocaproic acid (EACA) and plasminogen-containing fractions were further purified by filtration chromatography. t-PA was from Biopool (Umeå, Sweden). Urokinase was purchased from Sanofi Winthrop (Gentilly, France).

\section{Plasminogen binding and activation assays}

H. pylori $\left(10^{8}\right.$ cells $)$ were incubated with plasminogen $(0-0.4 \mu \mathrm{M})$ in $0.1 \mathrm{ml}$ PBS containing $1 \% \mathrm{BSA}$ for $1 \mathrm{~h}$ at $25^{\circ} \mathrm{C}$ under continuous mixing. At the end of the incubation period, the cells were pelleted. Bacteria were washed with 10 volumes of PBS containing $0.1 \%$ Tween 20 followed by washing in 50 $\mathrm{mM}$ Tris $\mathrm{HCl}, \mathrm{pH} 7.4$ (assay buffer), and finally resuspended in assay buffer. Bound plasminogen was activated with t-PA and the resultant plasmin activity monitored in the mixture at $405 \mathrm{~nm}$ with the chromogenic substrate CBS 00.65 (0.5 mM) after $30 \mathrm{~min}$ incubation at $37^{\circ} \mathrm{C}$.

Plasminogen activation by t-PA was studied in the presence or absence of $H$. pylori cells. For this purpose, $1.5 \mu \mathrm{M}$ plasminogen, $2.1 \mathrm{nM}$ t-PA, $0.5 \mathrm{mM}$ CBS 00.65 and increasing cell concentrations from $10^{7}$ to $10^{9} \%$ $\mathrm{ml}$ were mixed in $0.1 \mathrm{ml}$ assay buffer. The $\mathrm{A}_{405}$ of the mixture was monitored continuously at $37^{\circ} \mathrm{C}$. Initial velocities of activation were calculated from plots of $\mathrm{A}_{405}$ versus $\mathrm{t}^{2}$, according to Wohl et al. (22).

\section{Detection of cell-associated t-PA and urokinase activity}

Urokinase and t-PA were tested for their ability to bind to the surface of $H$. pylori cells. For this, increasing concentrations of both activators (0-14 nM t-PA; 0-50 nM urokinase) were incubated with $10^{8} \mathrm{H}$. pylori cells as described above. Washed cells were incubated with plasminogen $(1.5 \mu \mathrm{M})$ in the presence of CBS $00.65(0.5 \mathrm{mM})$. The $\mathrm{A}_{405}$ of the mixture was recorded at different time intervals, and plotted against the PA concentration.

\section{Affinity chromatography assays}

Human plasminogen was covalently coupled to NHS-activated Sepharose (HiTrap; Pharmacia) according to the manufacturer's instructions. H. pylori protein fractions were batch adsorbed to the plasminogen-Sepharose resine in PBS for $1 \mathrm{~h}$ at room temperature under continuous shaking. Following extensive washing with PBS, bound proteins were eluted with either $50 \mathrm{mM}$ EACA or $50 \mathrm{mM}$ glycine, $0.1 \mathrm{M} \mathrm{NaCl}, \mathrm{pH}$ 2.7 , and further analyzed by SDS-PAGE.

\section{Electrophoresis}

SDS-PAGE was performed according to Laemmli (23). H. pylori total cell extracts, surface proteins extracted with water, both obtained in the presence of $0.2 \mathrm{mM}$ phenylmethylsulfonyl fluoride and $1 \mathrm{mM}$ benzamidine, as well as proteins eluted from plasminogen-Sepharose assays, were separated on $10 \%$ acrylamide gels under reducing conditions. The proteins were not boiled prior to electrophoresis and were silver stained.

\section{Results}

\section{Plasminogen binding and activation on the surface of $\mathbf{H}$. pylori}

Purified human plasminogen was tested for its ability to bind and be activated on the surface of a clinical isolate of $H$. pylori. Figure 1 shows that t-PA is able to generate a surface plasmin activity to an extent which is strongly dependent on the initial concentration of the plasminogen allowed to bind to the bacteria. The acquisition of enzymatic activity was absolutely dependent on the presence of plasminogen; furthermore, the isolate tested did not exhibit surface plasmin activity in the absence of an exogenous activator (data not shown). 
Figure 1 - Activation of plasminogen to plasmin on the surface of $\mathrm{H}$. pylori. Cells $\left(10^{8}\right)$ were incubated with different amounts of human plasminogen. After extensive washing, surface-bound plasminogen was activated with $2.1 \mathrm{nM}$ t-PA. Plasmin activity was detected by digestion of the chromogenic substrate CBS 00.65 after 30-min incubation at $37^{\circ} \mathrm{C}$ (circles). Data are reported as the mean change in milliunits of absorbance at $405 \mathrm{~nm}$ obtained from at least three determinations. Standard errors are shown.

Figure 2 - Plasminogen-Sepharose affinity purification of plasminogen-binding protein. $\mathrm{H}$. pylori water extracts of surface proteins were allowed to bind to plasminogen-Sepharose for $1 \mathrm{~h}$. After extensive washing, bound proteins were eluted with 50 mM EACA and further analyzed by SDS-PAGE under reducing conditions. Lane 1, Molecular mass standards; lane 2, water extract of surface proteins; lane 3 , purified proteins after elution from plasminogen-Sepharose affinity matrix. The arrow indicates the position of the 58.9-kDa plasminogen-binding protein.
$H$. pylori proteins involved in the interaction with human plasminogen were isolated by affinity chromatography. This assay revealed the presence of one polypeptide of $58.9 \mathrm{kDa}$ in water extracts of surface proteins (Figure 2). This protein was eluted with
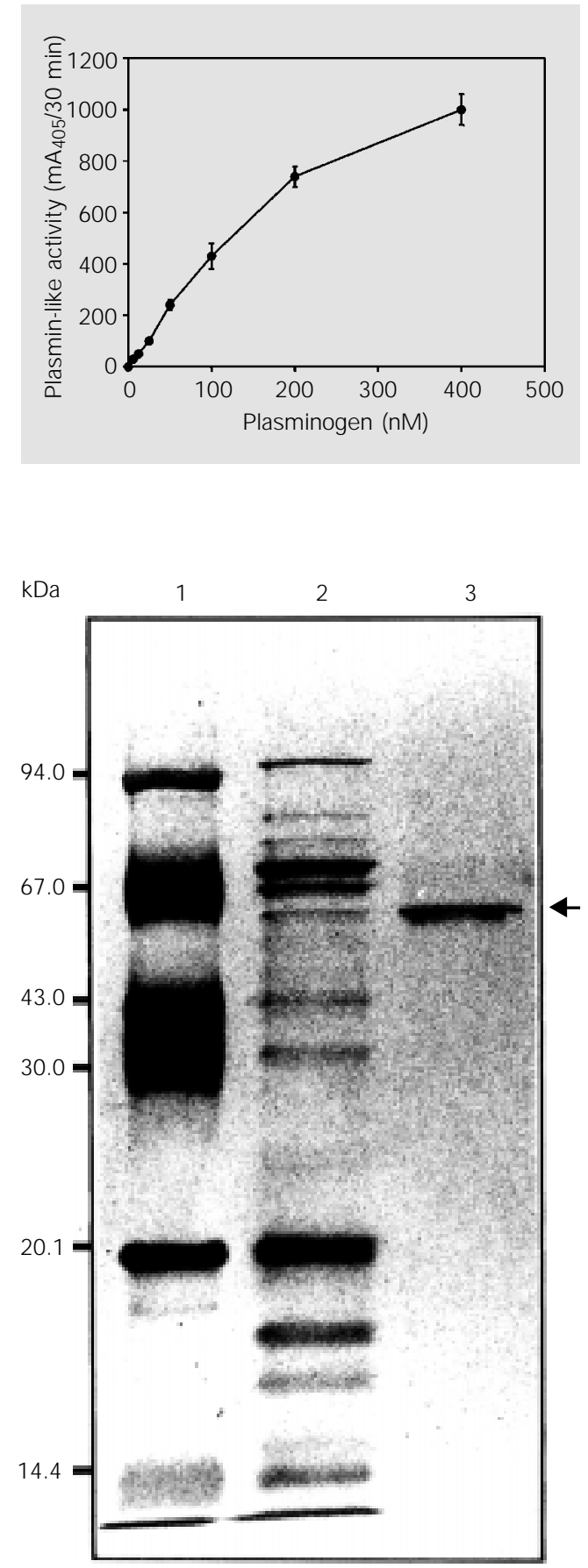

50 mM EACA; however, the same result was obtained when glycine buffer, $\mathrm{pH}$ 2.7, was used in the elution step.

\section{Enhancement of t-PA-catalyzed plasminogen activation by $\mathrm{H}$. pylori cells}

The effect of $H$. pylori cells on plasminogen activation rate by t-PA and urokinase was explored. When t-PA was the activator used, as shown in Figure 3, the addition of cells induced $\mathrm{a} \approx 25$-fold higher amidolytic activity (expressed in $\mathrm{mA}_{405} / \mathrm{min}^{2}$ ) compared with the activity in the absence of cells. In contrast to t-PA, when bacteria were incubated with plasminogen and urokinase under conditions identical to those used in the t-PA experiment, only a two-fold increase in plasminogen activation was observed (Figure 3 ). It thus appears that $H$. pylori enhancement of plasminogen activation is more specific with t-PA.

It was also observed that the initial rate of plasminogen activation (expressed as $\mathrm{mA}_{405} /$ $\min ^{2}$ ) increased significantly with cell concentration (Figure 4). A definite effect was seen at bacterial concentrations as low as $5 \mathrm{x}$ $10^{7}$ cells $/ \mathrm{ml}$.

\section{Binding of t-PA and urokinase to $\mathrm{H}$. pylori}

To assess whether $H$. pylori cells may express surface receptors for physiological plasminogen activators, a binding assay was developed. In both cases, an enzymatic activity proportional to the initial concentration of the activator was observed (Figure 5A and $\mathrm{B}$ ), showing that both activators bind to the surface of $H$. pylori cells in a concentration-dependent manner and are able to activate plasminogen. These results suggest that the activators remain active following immobilization on the surface of bacterial cells. The interaction between t-PA and $H$. pylori cells was inhibited by addition of the lysine analogue EACA, as shown in Figure $5 \mathrm{~A}$ (inset). 


\section{Discussion}

Plasminogen binding and activation on the surface of pathogenic bacteria have been implied in the invasion of tissues, hydrolysis of host immunoglobulins as well as availability of peptides from proteins for bacterial growth $(11,24,25)$. Several mechanisms are used by these organisms to activate host plasminogen. These include the expression of membrane-anchored activators, the secretion of soluble activators and/or the presence of receptors for both plasminogen and its physiological activators on the surface of bacteria (10). H. pylori has been recently added to the list of such organisms due to its ability to bind plasminogen, a zymogen which may be subsequently activated by host activators (19).

In the present study, we demonstrated that a clinical isolate of $H$. pylori is able to bind not only human plasminogen but also the two physiological activators, t-PA and urokinase. Binding of t-PA to $H$. pylori was inhibited by the lysine analogue EACA, suggesting an important role of the lysine-binding sites located in the activator kringle 2 structure (12). We also demonstrated that, once bound, these proteins remain active and may be used by the cells to express a surface plasmin activity. This strategy appears to be a common and efficient mechanism shared by invasive pathogens (11). It has already been observed that Borrelia burgdorferi expresses a receptor for urokinase in addition to binding plasminogen and that Escherichia coli and Salmonella enteritidis bind both t-PA and plasminogen, suggesting that organisms which bind plasminogen but do not produce their own plasminogen activators may acquire surface plasmin activity through host activators (10). H. pylori can be now included in this class of pathogens which share an alternative strategy to efficiently acquire cell-surface, unregulatable, plasmin activity under physiological conditions. Although we believe it is likely that specific

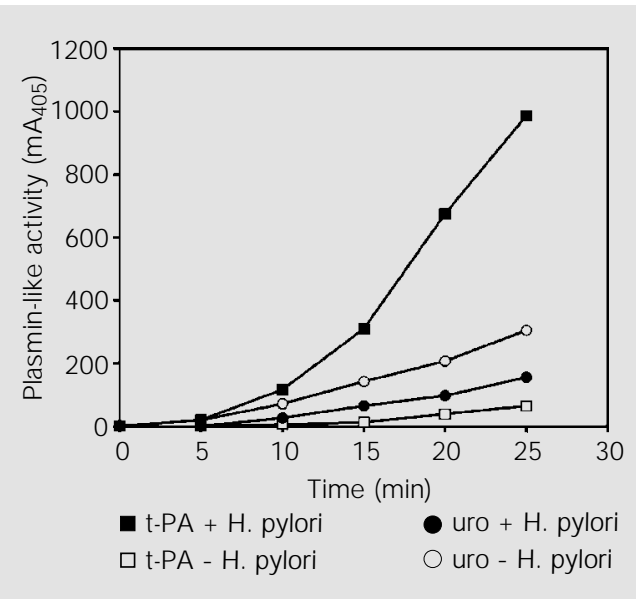

Figure 3 - Effect of $\mathrm{H}$. pylori cells on t-PA- and urokinase-catalyzed plasmin formation. Human plasminogen $(0.4 \mu \mathrm{M})$ was activated by $2.1 \mathrm{nM}$ t-PA (squares) or 0.2 $\mathrm{nM}$ urokinase (circles) in the presence (filled symbols) and absence (open symbols) of $10^{8} \mathrm{H}$. pylori cells. The formation of plasmin activity was measured using a chromogenic substrate.

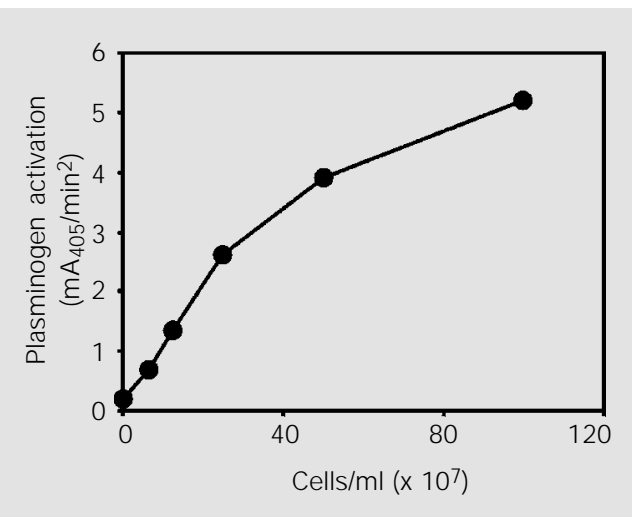

Figure 4 - Effect of cell density on t-PA-catalyzed plasminogen activation. Plasminogen $(1.5 \mu \mathrm{M})$ was activated with $2.1 \mathrm{nM}$ t-PA in the presence of increasing concentrations of $\mathrm{H}$. pylori cells. The resultant plasmin activity was measured with the chromogenic substrate CBS 00.65 at different time intervals and the initial rates of plasmin generation determined. Each point represents the mean value of at least three determinations.

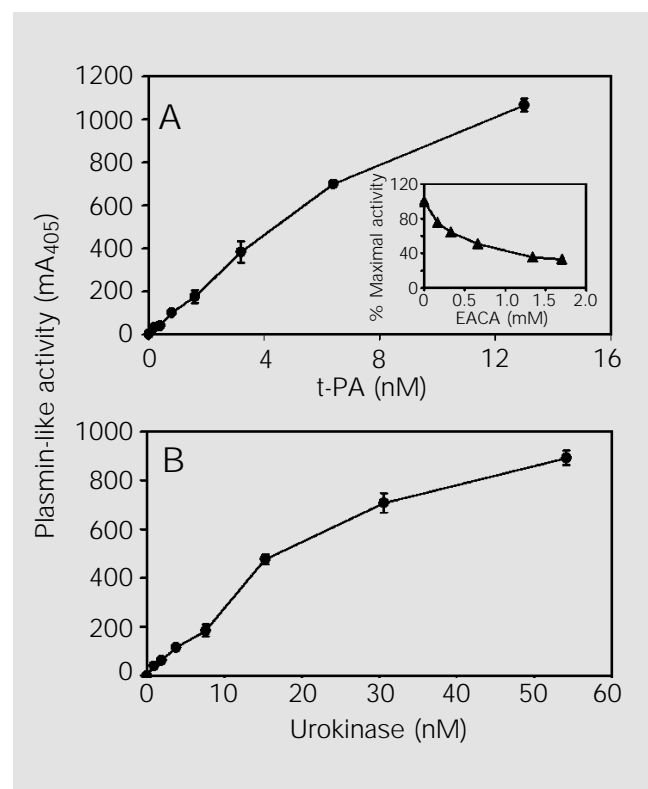

Figure 5 - t-PA and urokinase binding to the surface of $\mathrm{H}$. pylori. Different amounts of t-PA (A) and urokinase (B) were allowed to interact with $10^{8} \mathrm{H}$. washing, plasminogen $(1.5 \mu \mathrm{M})$ was added and the resultant plasmin activity recorded with CBS 00.65 after 5-min (urokinase) or 15-min (t-PA) incubation at $37^{\circ} \mathrm{C}$. Each point represents the mean value of at least three determinations. Standard errors are shown. Inset, Inhibition by $\varepsilon^{-}$ aminocaproic acid (EACA) of the binding of t-PA (14 nM) to $\mathrm{H}$. pylori cells. pylori cells. Following extensive 
receptors for both t-PA and urokinase may be present on the surface of $H$. pylori cells, their identity remains obscure and needs further experiments to be elucidated.

The receptors for human plasminogen in several pathogenic bacteria have been characterized (10). In the case of group A streptococci, such proteins appear to play a significant biological role since almost four different proteins are produced by these species (26). In the particular case of $H$. pylori, two proteins of 42 and $57 \mathrm{kDa}$ have been recently demonstrated to be involved in plasminogen binding, using immunoblot procedures (19). In the present study, with a different experimental approach, affinity binding assays of water extracts of surface proteins allowed the detection of a plasminogen-binding polypeptide of $58.9 \mathrm{kDa}$, a protein of a molecular mass similar to that of one of the proteins found in the other strain of $H$. pylori already studied (19). This protein was eluted with EACA, indicating specific binding through lysine-binding sites in the plasminogen molecule. The identification of this protein will allow to determine whether it is structurally related to other proteins which have been identified as plasminogen receptors $(27,28)$.

A significant enhancement of plasminogen activation by t-PA in the presence of $H$. pylori cells has been clearly established; when urokinase was used, only small differences were seen. These results are not surprising since others have observed the same behavior in the presence of platelets (7). It is well known that plasminogen activation in vivo is a surface-dependent reaction that offers a catalytic advantage for enzyme complex formation and that assembly of plasminogen and plasminogen activators on many cell types facilitates plasmin generation (reviewed in 29). Molecular assembly of t-PA and plasminogen on the surface of fibrin or cells results in a ternary complex that leads to a profound enhancement of the reaction rate (29). In the case of platelets, this enhancement appears to be particularly efficient when t-PA is the activator, resulting in a 5- to 8-fold increase in catalytic efficiency; however, when either urokinase or streptokinase is used, no enhancement is observed (7). Furthermore, enhancement of plasminogen activation by a number of bacteria expressing receptors for t-PA has been reported $(10,30)$. These observations correlate with the requirement of a third macromolecular component for the formation of a complex between plasminogen and t-PA. Fibrin, casein, denatured proteins, aggregated $\mathrm{IgG}$ and the eukaryotic cell surface are among the factors which enhance the activation of plasminogen $(31,32)$. In agreement with this, it is tempting to speculate that the cell surface of $H$. pylori may also promote complex formation between plasminogen and t-PA through specific receptors, leading to the pronounced rate of activation observed. From a biological perspective, our data suggest that $\mathrm{t}-\mathrm{PA}$, instead of urokinase, might be the physiological activator of plasminogen on the $H$. pylori surface. However, a decrease in t-PA and an increase in urokinase levels in H. pylori-associated gastritis have been previously reported (33). The activator responsible for the in vivo plasmin formation on the H. pylori surface is still to be elucidated.

The biological role of the interaction of H. pylori cells with components of the fibrinolytic system remains unclear, since this pathogen has not been demonstrated yet to invade host tissues, like other pathogenic bacteria (34). Nevertheless, plasmin-like surface activity may be used by these bacteria to degrade host proteins, like immunoglobulins (24), to obtain low molecular weight peptides for growth and survival (25) and/or to activate latent metalloproteinases (35). 


\section{References}

1. Ponting CP, Marshall J $M \&$ CederholmWilliams SA (1992). Plasminogen: a structural review. Blood Coagulation and $\mathrm{Fi}-$ brinolysis, 3: 605-614.

2. Robbins RC (1987). The plasminogenplasmin enzyme system. In: Coleman RW, Hirsh J, Marder VJ \& Salzman EW (Editors), Hemostasis and Thrombosis. Lippincott, Philadelphia.

3. Castellino FJ \& Powell J R (1981). Human plasminogen. Methods in Enzymology, 80: 365-378

4. Strickland S, Reich E \& Sherman MI (1976). Plasminogen activator in early embryogenesis: Enzyme production by trophoblast and parietal endoderm. Cell, 9: 231-240.

5. McNeill H \& Jensen PJ (1990). A highaffinity receptor for urokinase plasminogen activator on human keratinocytes: characterization and potential modulation during migration. Cell Regulation, 1: 843852.

6. Danø K, Andreasen PA, Grøndahl-Hansen J , Kristensen P, Nielsen LS \& Skriver L (1985). Plasminogen activators, tissue degradation and cancer. Advances in Cancer Research, 44: 139-266.

7. Gao S, Morser J, McLean K \& Shuman M (1990). Differential effect of platelets on plasminogen activation by tissue plasminogen activator, urokinase and streptokinase. Thrombosis Research, 58: 421-433.

8. Lijnen HR, Bachmann F, Collen D, Ellis V, Pannekoek H, Rijken DC \& Thorsen S (1994). Mechanisms of plasminogen activation. J ournal of Intemal Medicine, 236: 415-424.

9. Miles LA \& Plow EF (1988). Plasminogen receptors: ubiquitous sites for cellular regulation of fibrinolysis. Fibrinolysis, 2: 61-71.

10. Boyle $M \& \&$ Lottenbergh R (1997). Plasminogen activation by invasive human pathogens. Thrombosis and Haemostasis, 77: 1-10.

11. Lottenbergh R, Minning-Wenz D \& Boyle MD (1994). Capturing host plasmin(ogen): a common mechanism for invasive pathogens? Trends in Microbiology, 22: 20-24.

12. Bachmann F (1995). Fibrinolytic agents. Fibrinolysis, 9: 1-15.
13. Vandenplas Y (1999). Helicobacter pylori infection. Clinical Microbiology and Infection, 5: 1-11.

14. Khin $M M$, Ringnér $M$, Aleljung $P$, Wadström T \& Ho B (1996). Binding of human plasminogen and lactoferrin by Helicobacter pylori coccoid forms. J ournal of Medical Microbiology, 45: 433-439.

15. Ringnér $M$, Paulsson $M \&$ Wadström $T$ (1992). Vitronectin binding by Helicobacter pylori. FEMS Microbiology and Immunology, 5: 219-224.

16. Ringnér $\mathrm{M}$, Valkonen $\mathrm{KH} \&$ Wadström $\mathrm{T}$ (1994). Binding of vitronectin and plasminogen to Helicobacter pylori. FEMS Immunology and Medical Microbiology, 9: 29-34.

17. Trust TJ, Doig P, Emödy L, Kienle Z, Wadström T \& O'Toole P (1991). Highaffinity binding of the basement membrane proteins collagen type IV and laminin to the gastric pathogen Helicobacter pylori. Infection and Immunity, 59: 43984404.

18. Valkonen $\mathrm{KH}$, Ringnér $\mathrm{M}$, Ljungh $\mathrm{A} \&$ Wadström T (1993). High affinity binding of laminin by Helicobacter pylori: evidence for a lectin-like interaction. FEMS Immunology and Medical Microbiology, 7: 2937.

19. Pantzar $M$, Ljungh $A \&$ Wadström $T$ (1998). Plasminogen binding and activation at the surface of Helicobacter pylori CCUG 17874. Infection and Immunity, 66: 4976-4980.

20. Raymond J, Begeret $\mathrm{M}$, Benhamou PH, Mensah K \& Dupont C (1994). A 2-year study of $\mathrm{H}$. pylori in children. J ournal of Clinical Microbiology, 32: 461-463.

21. Deutsch DG \& Mertz ET (1970). Plasminogen: purification from human plasma by affinity chromatography. Science, 170: 1095-1096.

22. Wohl RC, Summaria $L \&$ Robbins $K C$ (1980). Kinetics of activation of human plasminogen by different activator species at pH 7.4 and 37 degrees C. J oumal of Biological Chemistry, 255: 2005-2013.

23. Laemmli UK (1970). Cleavage of structural proteins during the assembly of the head of bacteriophage T4. Nature, 227: 680-685.
24. Chuba JV (1994). Susceptibility of monoclonal IgG paraproteins to plasmin cleavage using glycerol stabilised human plasmin. Biochemical and Biophysical Research Communications, 202: 367-373.

25. Leigh J A (1993). Activation of bovine plasminogen by Streptococcus uberis. FEMS Microbiology Letters, 114: 67-72.

26. Poon-King R, Bannan J , Viteri A, Cu G \& Zabriskie JB (1993). Identification of an extracellular plasmin binding protein from nephritogenic streptococci. J ournal of Experimental Medicine, 1178: 759-763.

27. Redlitz A \& Plow EF (1995). Receptors for plasminogen and t-PA: an update. Baillieres Clinical Haematology, 8: 313-327.

28. Pancholi V \& Fischetti VA (1998). Alphaenolase, a novel strong plasmin(ogen) binding protein on the surface of pathogenic streptococci. J oumal of Biological Chemistry, 273: 14503-14515.

29. Anglés-Cano E (1994). Overview on fibrinolysis: plasminogen activation pathways on fibrin and cell surfaces. Chemistry and Physics of Lipids, 67/68: 353-362.

30. Lähteenmäki K, Westerlund $B$, Kuusela $P$ \& Korhonen TK (1993). Immobilization of plasminogen on Escherichia coli flagella. FEMS Microbiology Letters, 106: 309314.

31. Kuusela P \& Saksela O (1990). Binding and activation of plasminogen at the surface of Staphylococcus aureus. Increase in affinity after conversion to the Lys form of the ligand. European J ournal of Biochemistry, 193: 759-765.

32. Machovich R \& Owen WG (1997). Denatured proteins as cofactors for plasminogen activation. Archives of Biochemistry and Biophysics, 15: 343-349.

33. Gotz J M, Vergouwe $Y$, Verspaget HW, Biemond I, Sier CF, Lamers CB \& Veenendaal RA (1996). Gastric mucosal plasminogen activators in Helicobacter pylori infection. Digestive Diseases and Sciences, 41: 1577-1582.

34. Scott D, Weeks D, Melchers K \& Sachs G (1998). The life and death of Helicobacter pylori. Gut, 43: S56-S60.

35. Mullins DE \& Rohrlich ST (1983). The role of proteases in cellular invasiveness. Biochimica et Biophysica Acta, 695: 177-214. 